\title{
SAMHD1 wt Allele
}

National Cancer Institute

\section{Source}

National Cancer Institute. SAMHD1 wt Allele. NCI Thesaurus. Code C98204.

Human SAMHD1 wild-type allele is located within 20pter-q12 and is approximately $62 \mathrm{~kb}$ in length. This allele, which encodes SAM domain and HD domain-containing protein 1, plays a role in the immune response and signaling pathways. Mutation of the gene is associated with Aicardi-Goutieres syndrome type 5. 